\title{
Uma confissão em fragmentos: Goethe, Fausto e o peregrino
}

MICHAEL JAEGER ${ }^{I}$

Foi assim que comecei a seguir aquele rumo do qual nunca mais conseguiria me desviar ao longo de toda minha vida: transformava em imagem, em poema tudo aquilo que me alegrasse e me atormentasse, ou que me ocupasse de algum modo. E, fazendo isso, resolvia as questões comigo mesmo, ora me obrigando a reformular minha compreensão do mundo, ora fazendo sossegar em mim minhas tantas inquietações. Ninguém tinha maior necessidade de um dom como esse do que eu mesmo, que vivia sendo constantemente arremessado de um extremo ao outro pela força de minha própria natureza. Portanto, todas as coisas que dei a público não são mais que fragmentos de uma grande confissão. E este livrinho, aqui, não passa de uma tentativa ousada de complementá-la.

(Da minha vida. Poesia e verdade (Goethe, 2017, p.343)

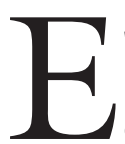

SSA DECLARAÇÃo sobre a escrita fragmentária e sua motivação crítico-terapêutica é confirmada justamente pela tragédia Fausto de modo mais drástico do que em qualquer outro texto da grande confissão de Goethe. Por toda a vida, ele empreendeu a ousada tentativa de tornar completos os fragmentos do Fausto, e publicou o drama de maneira fragmentária. Somente a edição póstuma uniu todas as partes em um Fausto completo.

A primeira edição crítica completa do Fausto foi preparada sob a direção de Anne Bohnenkamp e, em 2018, apresentada pela casa de Goethe em Frankfurt. Primeiramente, isso significa que se tornaram visíveis os incontáveis fragmentos com os quais Goethe compôs, entre 1770 e 1831, o texto completo da tragédia. Assim, todas as diversas camadas do texto, trechos manuscritos dispersos, cópias, acréscimos, revisões, rasuras, sobrescritos e variações foram reunidos em uma edição histórico-crítica. ${ }^{1}$ Não havia até então uma edição crítica integral do Fausto pelo fato de esse conjunto de fragmentos textuais ocupar posição singular na literatura alemã, devido à sua extensão colossal, fruto de sucessivos acréscimos ao longo de mais de sessenta anos. A massa total de fragmentos havia excedido, até então, as possibilidades de apresentação que utilizavam métodos tradicionais de impressão. Agora é possível se servir da nova possibilidade de uma edição eletrônica do texto, pela qual é possível, com um clique do mouse, trazer à tela qualquer fragmento até mesmo das camadas mais longínquas do texto. É também possível acompanhar todos os passos intermediários da interminável gênese textual, fracionada e interrompida diversas vezes. 
Não fosse o bastante, Goethe, como autor, sempre trabalhou em "todas as coisas" que "deu a público" sob o princípio do fragmento, precisamente como exprimiu na confissão em Poesia e verdade citada acima. Goethe utilizava um procedimento de escrita que lhe permitia acrescentar novos fragmentos aos textos já concebidos como fragmento, e assim também agregar novos significados, sempre segundo alterações resultantes de circunstâncias particulares ou políticas.

$\mathrm{Na}$ verdade, a confissão de Goethe sobre a escrita aberta e fragmentária vale para toda a sua obra. De maneira alguma ele passou a vida inteira trabalhando somente com o Fausto; passou a vida trabalhando também com os romances de Wilhelm Meister, desde a Missão teatral, passando pelos Anos de aprendizagem, até os Anos de peregrinação (e suas duas versões). E, durante toda a vida, Goethe escreveu tendo em mente o fragmento, especialmente em sua autobiografia, estruturada no todo e em suas diversas partes também segundo o princípio do fragmento. A edição crítica integral do Fausto não seria muito diferente da edição crítica integral das memórias de sua viagem à Itália, iniciadas com as cartas italianas de Goethe e com o diário para Frau von Stein em setembro de 1786. O texto das memórias também passou por um encadeamento interminável de rasuras, acréscimos, reelaborações e variações, até resultar nos dois primeiros volumes da Viagem à Itália, em 1816 e 1817, e na Segunda estadia romana, a qual Goethe somente acrescentou à sua Viagem à Itália em 1829, quarenta anos depois da viagem às terras do sul.

Baseando-me em uma visão sincrônica das memórias italianas de Goethe e de seu drama fáustico, demonstrarei neste ensaio que Goethe escreveu "uma grande confissão", pode-se dizer uma confissão completa, em diversas partes. A relação íntima dos fragmentos italianos com os fragmentos de Fausto ficará clara. Ao mesmo tempo, ao reunir todos os fragmentos, serão postas em evidência as quebras e as contradições na obra e na vida de Goethe.

\section{Tornar as contradições mais disparatadas}

Em uma anotação feita por volta de 1800 sobre o Fausto, Goethe exigiu de si mesmo tornar as "contradições" em seu texto, "ao invés de unificadas, mais disparatadas" (Goethe, 1994, v.7/1, p.577). A partir dessa anotação de Goethe, não é possível concluir claramente quais são as contradições a que ele se refere. Em todo caso, ambos os conceitos típicos do Fausto, que estão em contraste entre si, são mencionados: "aspiração" e "fruição". Se, entretanto, se analisa a volumosa troca de cartas entre Goethe e Schiller sobre o Fausto, cartas escritas nessa mesma época, notam-se contradições disparatadas em toda parte.

Entre elas, dois pares opositivos chamam a atenção: por um lado, a contradição entre a inclinação de Goethe ao fragmentário, ligada persistentemente aos esforços com o Fausto, e, por outro lado, sua inclinação à obra como um todo. Schiller exige, sob censuras, uma ideia unificante e filosófica ao todo da obra. Goethe, porém, teima - um tanto relutante e ao mesmo tempo desamparado - em uma característica genuinamente fragmentária de seu trabalho no Fausto: 
“junto ao todo" restará “sempre um fragmento", como comunica a Schiller (ibidem, p.775).

O segundo par de opostos que chama a atenção na troca de cartas entre Goethe e Schiller parece ser aquele responsável pela desintegração do todo do Fausto em fragmentos: os pares Barbárie e Beleza, Fausto e Helena, névoa alemã e clareza mediterrânea (ibidem, p.722ss), entre "espectro do norte e reminiscências do sul", como Goethe escreve a Schiller (ibidem). As "reminiscências do sul" são as memórias italianas de Goethe e os "espectros do norte" são as lendas do doutor Fausto.

Tendo em mente a nostalgia italiana de Goethe, Schiller atenta para os riscos que são despertados por essa contradição para a inteireza do drama, motivo pelo qual ele adverte Goethe: "o Senhor precisa, portanto, afirmar em seu Fausto a lei do mais forte (Faustrecht)" (ibidem, p.781). Claramente, esse conselho substancial se choca com a preferência de Goethe pelas "reminiscências do sul", de forma que Schiller, quase já resignado, comunica ao editor do Fausto, Cotta, a seguinte impressão sobre o hesitante autor do Fausto: "pelos seus planos e os fundamentos que segue, temo que mais nada surgirá se não houver uma grande mudança nele. Ele é pouco senhor de sua disposição [...] Quase perco as esperanças de que chegue a terminar seu Fausto" (ibidem, p.783).

\section{Operações romanas sobre o Fausto: esborratar - cenas velhas e novas}

Para conhecer mais detalhes sobre a contradição, que desfaz o todo da obra em fragmentos, entre o espectro fáustico do norte e as "reminiscências do sul" de Goethe - reminiscências que são senhoras de sua disposição -, isto é, para entender o conflito entre Fausto e o sul, é necessário observar a gênese dessa contradição e seguir Goethe até a fonte de suas memórias do sul, portanto, à Itália. Como peregrino na Itália, Goethe colocou-se pela primeira vez em contradição com o "espectro (aéreo)", Fausto.

Na parte de correspondências da Segunda estadia romana, Goethe relata, sob a data "Roma, $1^{\circ}$ de março" de 1788 , que enfim pretendia concluir os manuscritos que estavam previstos para a edição em oito volumes de seus "Escritos", publicados desde 1787. Ele o conseguiu no caso da Ifigênia e de Egmont. Agora, ainda estavam na programação ambos os dramas Tasso e Fausto. Evidentemente, tratava-se de tarefas complicadas nas quais o peregrino na Itália até então não havia mexido por uma boa razão. Ele explicou essa razão somente próximo ao fim de seus dias de viagem, que durou quase dois anos, de maneira um tanto angustiada: "tive a coragem de ponderar de uma única vez sobre os três últimos volumes, e agora sei precisamente o que farei [o que ele até esse ponto não sabia ]; que o céu me dê ânimo e sorte para fazê-lo" (Goethe, 1998, v.11, p.525).

Assim, Goethe nos permite uma visão dentro da oficina romana de Fausto. Uma cena paradoxal se abre diante de nossos olhos: da perspectiva do famoso quadro de Tischbein, um Goethe olha curioso da janela de sua casa no Corso 
romano; então ele se vira, toma o velho manuscrito da tragédia e se dispõe, sentado à escrivaninha e cercado de moldes de antigas esculturas, a continuar o drama do mago Fausto, depressivo e alemão até o cerne, esse Fausto que, no quarto gótico, cercado de “ossadas de homens e animais" (v.417), declamará seu monólogo em pleno desespero.

Não é possível apresentar de maneira mais contraditória a situação do autor romano do Fausto. E essa contradição - entre sul e norte, entre o Goethe que peregrinava pela Itália e seu Fausto - marca, a partir de então, o trabalho no manuscrito da tragédia, que foi concluído somente no verão de 1831 . No final da vida de Goethe, tal contradição entre o peregrino e Fausto irromperá em uma catástrofe.

A mesma correspondência italiana de Goethe de março de 1788 deixa claro que ele inseriu dentro da forma de seu velho texto do Fausto algo completamente inapropriado à república dos artistas do Corso romano. Ele nos informa meticulosamente: "primeiramente, o plano do Fausto foi desenhado, e espero que eu tenha êxito nessa operação”. No entanto, logo em seguida, Goethe acrescenta de forma restritiva: "Naturalmente é outra coisa escrever a peça agora [em Roma, março de 1788] do que há quinze anos [época em que, como se sabe, iniciou o drama fáustico, em 1773, ainda na casa dos pais em Frankfurt], especialmente porque agora creio ter reencontrado o fio [o qual ele havia perdido no decorrer dos quinze anos anteriores]. Também no que concerne ao tom do todo, sinto-me consolado; já idealizei uma nova cena e, quando eu fumigar o papel, então, penso, ninguém a encontraria no meio das cenas antigas" (ibidem, v.11, p.525).

Em Roma, em um tipo de oficina de falsificação, o autor do Fausto parece seguir exercendo sua atividade não completamente estranha de esborratar as novas cenas por fumigação a fim de lhes conferir uma pátina adicional e antiquada para que ninguém possa distinguir no texto as diferentes épocas de surgimento das cenas e os fragmentos de vida ligados a elas. Dirigindo o olhar das partes heterogêneas do manuscrito para as diferentes épocas da vida, Goethe acrescenta, admirado, sobre si mesmo: "porque fui trazido de volta a mim, por meio de longa paz e de solidão [na Itália], ao nível da minha própria existência; é notável o quanto estou igual e quão pouco meu íntimo sofrera através dos anos e dos acontecimentos" (ibidem).

Podemos acrescentar: apesar de uma história de sofrimento durante os anos anteriores, seu íntimo e, portanto, sua própria existência autêntica se preservaram no que estava oculto, antes que esse oculto reaparecesse por meio da tranquilidade existencial que foi alcançada na fuga para a Itália. A seguir, Goethe novamente examina, em março de 1788, o texto do Fausto, como se se tratasse do corpo velho e maltratado de sua própria história de sofrimento:

“às vezes, quando o vejo diante de mim, o velho manuscrito me faz pensar. É ainda a primeira versão, as cenas principais foram escritas assim, sem 
rascunho [por volta de 1773, as cenas noturnas de Fausto, 'No quarto gótico', e a tragédia de Margarida foram 'escritas assim, sem rascunho']; agora, ele está amarelado pelo tempo, tão puído [...], tão gasto e esfarelado nas bordas que realmente se parece com o fragmento de um códex antigo. Assim como antes me transportei com mente e intuição a um mundo anterior, agora preciso me transportar novamente a um passado vivenciado por mim mesmo".

O autor do Fausto já então lidava com camadas temporais duplas, conforme o declarou com algum enfado. Devido à retomada do trabalho no manuscrito do Fausto, Goethe precisa não só se transportar àquele "passado vivenciado por mim mesmo", durante o qual começou a trabalhar com as primeiras "cenas principais" à época do movimento juvenil Sturm und Drang [Tempestade e Ímpeto], mas também precisa, seguindo sua antiga fascinação pelo gótico, acompanhar o herói da tragédia ao "mundo anterior" do "quarto gótico", e precisa fazê-lo precisamente em Roma, o centro do clássico. Na correspondência italiana de março de 1788 se inicia aquela longa lista de lamentações sobre a contradição interna de seu trabalho no drama fáustico. Porque esse trabalho duraria toda a sua vida, as contradições sempre cresceriam, assim como as lamentações do autor sempre acompanhariam o processo de composição até chegar à recusa de publicação cinco dias antes de sua morte, conforme dito em sua última carta a Wilhelm von Humboldt.

\section{Uma carcaça em ruínas. O manuscrito de Fausto de 1832}

Nessa ocasião, Goethe abordou uma última vez aquelas energias dilacerantes que foram liberadas pela dissociação crescente entre as diferentes camadas temporais, existenciais e textuais, dissociação essa ligada ao trabalho vitalício no manuscrito do Fausto. Em março de 1832, em seu quarto de trabalho em Weimar, Goethe ainda se encontrava na mesma situação na qual o vimos já em sua acomodação no Corso romano, ou seja, tentando unir em um todo as partes disparatadas do drama que surgiram em épocas de vida distantes. Goethe fala, em uma carta de 17 de março de 1832 a Humboldt, sobre os esforços para terminar o Fausto: "aqui, no entanto, sucedeu a grande dificuldade de alcançar [na velhice], por meio de propósito e caráter, aquilo que, na verdade, deveria ocorrer à natureza [à juventude] espontânea e ativa" (Goethe, 1994, 7/1, p.812).

Se aquilo tivesse acontecido ainda em Roma em 1788 (serem "fumegadas" as novas cenas do Fausto para que "ninguém" as pudesse "distinguir das antigas"), Goethe não teria ficado especialmente preocupado, em 1832, com uma possível não uniformidade da forma da tragédia. "Eu não temeria", assim escreve a Humboldt, "que as pessoas pudessem diferenciar o velho do novo, o posterior do anterior; podemos confiar isso ao exame benevolente dos futuros leitores" (ibidem).

O temor de Goethe está relacionado, na velhice, àquela outra diferença temporal entre seu próprio anacronismo e o tempo corrente no ano de 1832 , que é marcado na Europa pelo signo da revolução industrial e das revoltas políti- 
cas. Em meio a relações tão turbulentas, segundo seu prognóstico, ele vê seu frágil edifício fáustico ser despedaçado pela incompreensão dos contemporâneos. Goethe segue dizendo a Humboldt: "o presente está verdadeiramente tão absurdo e tão confuso que me convenço de que meus honestos esforços há tempos dedicados a esse edifício estranho [a tragédia Fausto] serão mal recompensados e jogados à praia; jazerão ali como uma carcaça em ruínas e então serão cobertos pelas dunas das horas" (ibidem). Diante desse estado sombrio, o selamento do manuscrito e a exigência de o Fausto completo ser uma obra póstuma são uma medida lógica.

\section{Fragmentos do Fausto, confissões de Goethe}

O tom irritado de Goethe pode estar relacionado ao fato de que a tragédia de Fausto é o fragmento mais significativo e, no entanto, mais frágil de sua grande confissão. Essa relação se torna clara quando olhamos para o esquema de Poesia e verdade que Goethe anotou para si mesmo em outubro de 1809, no momento da concepção de sua descrição de vida: "minha vida", ele diz, "é uma aventura única. Não uma aventura pela aspiração a aperfeiçoar aquilo que a natureza colocou em mim. Aspiração a adquirir aquilo que ela não colocou em mim. Intenção tão verdadeira quanto falsa. Por isso, tortura eterna sem gozo verdadeiro" (Goethes werke, I, v.26, p.364; Goethe, 1994, v.14, p.1055).

Ficamos em alerta, pois Goethe fala como autobiógrafo em "aspirar", o que reconhecemos como uma palavra fáustica par excellence. Goethe fala especialmente da "aspiração a adquirir" justamente aquilo que a natureza não colocou nele, porque essa aspiração promove a contradição entre "intenção" "verdadeira" e "falsa" e o leva à "tortura eterna sem gozo verdadeiro". "Tortura eterna sem gozo verdadeiro", por outro lado, é uma descrição precisa da disposição anímica no "quarto gótico" e, portanto, de Fausto.

No entanto, tais relações dentro da grande confissão nunca seriam abertamente expressas por Goethe. O drama Fausto parece estar virtualmente sujeito a um voto de silêncio. Na correspondência romana de março de 1788, Goethe somente nos comunicou que desejava encobrir as fraturas entre partes antigas e partes que ainda viriam da tragédia por meio do esborratar uniforme do texto completo. Porém, sobre aquilo que ainda viria e sobre aquilo que ocorreu por causa de algumas experiências italianas, nada sabemos.

Isso também vale para outras raras informações sobre o Fausto, sempre um tanto estranhas, em suas cartas italianas. Nelas, Fausto nos aparece principalmente como fardo, como agente da melancolia e, por isso, fora de lugar na euforia mediterrânea. Em regra, ele se apresenta como companheiro de Tasso. Ambos os melancólicos personificam o fardo do qual o viajante ao sul finalmente se livra e que pretende transformar em poesia. Já um tanto esgotado, anuncia em Roma, em novembro de 1787: "ainda há duas rochas diante de mim: Fausto e Tasso. Porque os compassivos deuses parecem ter me remido da pena de Sísifo para o futuro, tenho esperança de também levar esses blocos montanha acima. 
Quando eu estiver lá, começa tudo de novo [...]" (Goethe, 1985, v.15, p.516). Goethe repete a alusão ao trabalho de Sísifo em fevereiro de 1788 em uma carta para o duque Carl August. Enquanto isso, já verificamos que, diferentemente da rocha de Tasso, o bloco de Fausto deve ser levado para cima de uma montanha incomparavelmente mais alta. Goethe: "Agora, não há quase mais nada diante de mim senão a colina Tasso e a montanha Faustus. Não descansarei dia ou noite até que ambos estejam terminados" (Goethes werke, IV, v.8, p.347).

\section{Fausto e Faustina}

Essas notícias sobre a heroica carga de trabalho depois da escapada à Itália não correspondem totalmente à verdade durante os primeiros meses de 1788 , pois Goethe passou dias alegres e sobretudo noites felizes não sob o signo de Fausto, mas sim sob a estrela de Faustina, a amada romana de Goethe. O trabalho de escrita no manuscrito de Fausto fica em repouso durante essa época feliz de Goethe. E, de fato, podemos falar também de tempo de incubação, durante o qual as novas ideias sobre o Fausto se desenvolviam: ex negativo, o drama Fausto espelha doravante as felizes experiências italianas. Então, desse momento em diante, Fausto nega categoricamente a existência feliz como um Infaustissimus. Significativas exceções são as cenas Floresta e gruta (Fausto I), e Região amena assim como os momentos passados na Grécia junto de Helena (Fausto II); essas exceções, no entanto, confirmam a regra da negação da felicidade por Fausto. Em consequência disso, a excepcional fúria do herói da tragédia direciona-se justamente à experiência italiana salvadora de Goethe, à experiência do momento belo, que permite ser possível a correspondência entre Si e o Mundo. Essa nova concepção do Fausto deve ter se manifestado a Goethe de maneira tão pavorosa que ele a internalizou imediatamente na esfera da vida acobertada pelo incógnito italiano. Por isso, falou nela somente de maneira críptica e em "fragmentos", como sempre o fazia quando se tratava de sua "grande confissão".

Os rompimentos vitais que ocorrem nas partes dessa confissão formidável raramente ficarão tão claros na obra de Goethe quanto na Segunda estadia romana. As memórias do mundo fáustico, sombrio e fumegado, agem anacronicamente no ambiente clássico e são seguidas pelas notícias felizes e cheias de luminosidade do peregrino italiano na mesma correspondência de março. Nela, ele confessa ter gozado da "mais elevada satisfação" de sua vida em Roma e ter conhecido o "ponto mais extremo" da felicidade. Além disso, a vista do lar romano eleva a euforia dessa correspondência - "diante da minha janela está o paraíso" (ibidem, p.529) -, assim como o reconhecimento pelo autobiógrafo de que, em Roma, "pela primeira vez se encontrou", ali "pela primeira vez correspondendo" consigo mesmo, tornando-se "feliz e sensato". Todas são autodeterminações antifáusticas que o autobiógrafo leva adiante no relato sobre o plano do Fausto romano e que nos permitem presumir qual "plano" foi pensado para o trabalho futuro no "velho manuscrito": Fausto e o peregrino italiano se tornam doravante adversários na grande confissão de Goethe. 


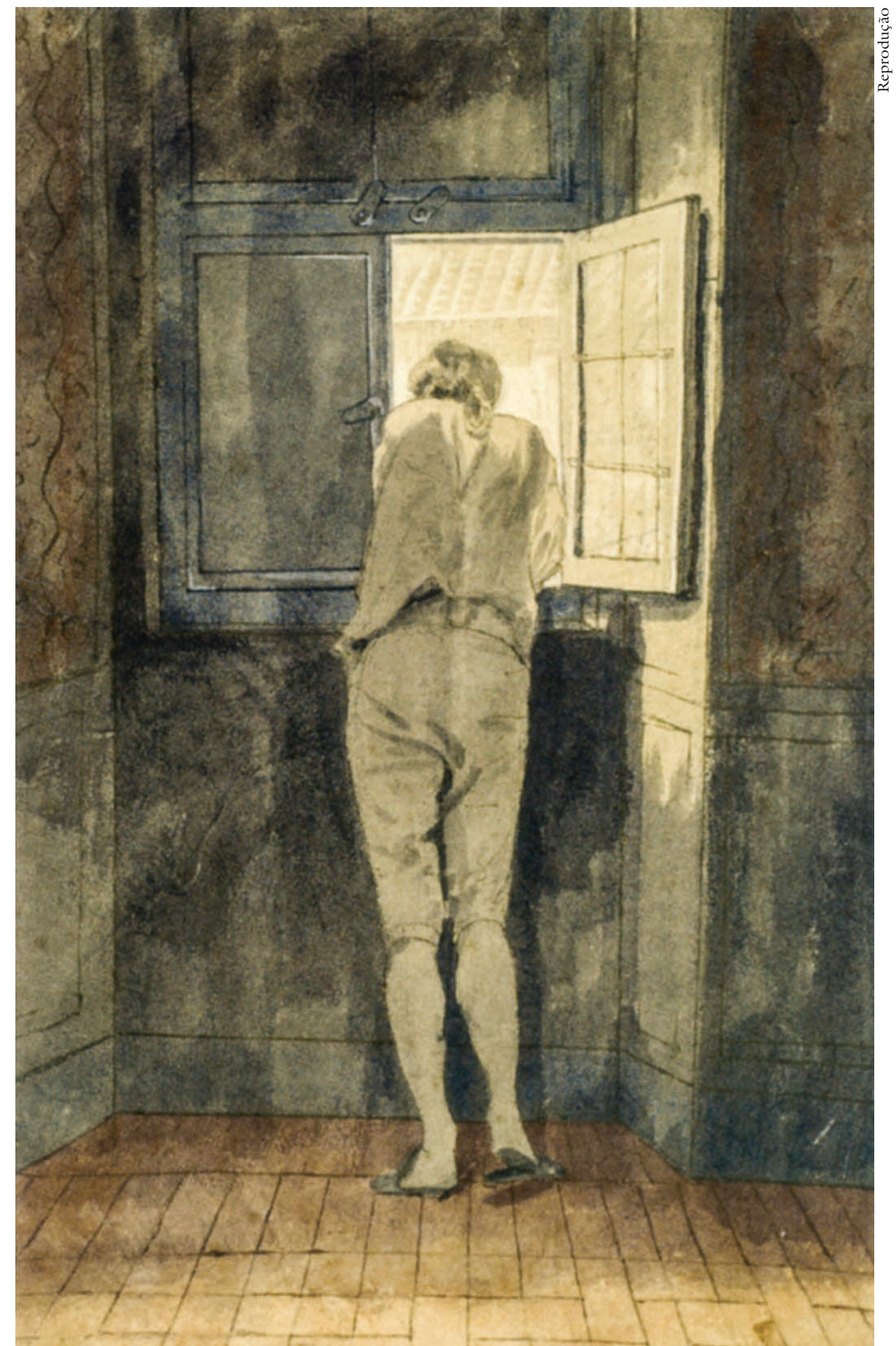

Goethe à janela de seu quarto em Roma, por J. H. W. Tischbein. 


\section{Depressão matinal e euforia matinal}

A contradição entre ambas essas figuras na obra de Goethe não poderia ser mais disparatada. Para demonstrá-lo usando um exemplo drástico: por volta da época em que mantém a correspondência com Schiller sobre o Fausto, Goethe escreve as duas cenas "Quarto de trabalho" da primeira parte do drama. Elas contêm a crítica radical de Fausto às suas condições de existência e preparam o pacto com Mefisto. E acrescente-se aqui o lamento amargo de Fausto:

Só com pavor desperto de manhã

quase a gemer de amargo dó,

ao ver o dia, que, em fugida vã,

não me cumpre um desejo, nem um só;

que até o presságio de algum gozo

com fútil critiquice exclui,

que as criações de meu espírito audacioso

com farsas mil da vida obstrui. [...]

O Deus, que o ser profundo me emociona

e me agita o âmago em que mora,

que acima de meus brios todos trona,

não pode atuar nada por fora.

E da existência, assim, o fardo me contrista,

a morte almejo, a vida me é malquista. (v.1554ss) ${ }^{2}$

$\mathrm{O}$ ódio de Fausto à vida responde a um contraste entre Si e Mundo, Desejo e Realidade, que é polêmico e intransponível a seus olhos. A fossa crítica do reconhecimento entre subjetividade e objetividade nunca é transponível; jamais o Interior e o Exterior se aproximam. No "Quarto gótico", Fausto vive como que em banimento e em exílio. Sua autoconsciência impotente está trancafiada no "cárcere" miserável do estranhamento total, do qual somente o desejo de morrer é capaz de levar a uma saída.

Essa depressão matinal de Fausto poderia ser confrontada com a euforia matinal e existencial do peregrino italiano Goethe que, logo que alcança o lado sul dos Alpes, exclama: "ali, sente-se novamente em casa no mundo, e não como que usurpado ou em exílio" (Goethe, 1998, 11, p.26). Tendo chegado a Veneza, seu resumo diário e entusiasmado diz: "um dia delicioso, desde a manhã até a madrugada!” (ibidem, p.90). Lá, ele viu o mar pela primeira vez e exclamou ao Lido: "Que coisa deliciosa e maravilhosa é esse ser vivo! Quão adaptado à sua condição, quão verdadeiro, quão si mesmo!” (ibidem, p.93). Incontáveis são as notas eufóricas do peregrino italiano que se contradizem aos diagnósticos inconsoláveis de Fausto acerca do fardo da existência e do ódio à vida.

Goethe faz uma confissão formal na Viagem à Itália e retrata sua conversão romana como um renascer e, por isso, apropria-se das imagens e citações correspondentes da tradição religiosa e teológica: "assim eu vivo feliz, porque vivo naquilo que é de meu Pai”, confessa o viajante italiano usando o evangelista 
Lucas na Segunda estadia romana (Goethe, 1998, 11, p.400). A correspondência espiritual entre Pai e Filho serve a Goethe como ilustração significativa de sua experiência mundana feliz: encontrar em Roma e na Itália o elemento vital completamente apropriado a ele. Com uma expressão profana, Goethe comenta sobre essa vivência existencial euforizante e particularmente estranha a Fausto: "só há uma Roma no mundo, e encontro-me aqui como o peixe dentro da água, e nado como uma bolinha de mercúrio que se dissolve em todos os outros fluidos" (ibidem, p.354).

\section{Novas cenas italianas: "Fausto. Mefistófeles"}

Quando nos lembramos dessa passagem da oficina romana do Fausto, na qual as novas cenas deveriam ser fumegadas, e nos perguntamos o que de fato Goethe trouxe consigo da Itália e para onde o grande bloco Fausto deveria ser rolado, então constatamos: ele trazia bem poucos versos fáusticos novos na bagagem quando voltou para Weimar. De fato, o texto que foi publicado em 1790 no sétimo volume dos Escritos de Goethe se chama "Fausto. Um fragmento". Comparando o fragmento de Fausto de 1790 com o "velho manuscrito" portanto, com o assim chamado "Urfaust" [Fausto Zero] encontrado somente muito depois -, vê-se que, desde a fuga para a Itália, somente as cenas "Fausto. Mefistófeles", "Cozinha da bruxa" e parte da cena "Floresta e gruta" foram acrescentadas.

No momento de maior desânimo, Goethe traz Mefisto para ajudar Fausto - ainda em Roma ou logo após a volta da Itália. Sem a transformação do cão, que foi acrescentada somente muito depois, Mefisto surge de repente no fragmento do Fausto de 1790. "Fausto. Mefistófeles.", diz a primeira linha italiana, de acordo com a cronologia do verso, que Goethe inseriu no velho manuscrito, como se agora Fausto tivesse se ampliado incorporando a dimensão de Mefisto.

Diante de seu novo companheiro, Fausto imediatamente provoca uma ampliação autossugestiva do seu próprio eu devido à sua impotência insuficientemente percebida: "E o que a toda a humanidade é doado, / quero gozar no próprio $\mathrm{Eu}$, a fundo, / com a alma lhe colher o vil e o mais perfeito, / juntar-lhe a dor e o bem-estar no peito, / e, destarte, ao seu Ser ampliar meu próprio Ser, / e, com ela, afinal, também eu perecer" (v.1770ss). Com a atitude do amigo experimentado, Mefisto repele tais ambições de Fausto acerca do todo da humanidade. "Podes crer-mo, esse Todo, filho, / só para um Deus é feito" (v.1780-1781).

Assombrando Fausto como uma obsessão, a utopia de uma relação direta entre o Eu e o Mundo, segundo a tentadora mensagem de Mefisto, não será realizada como conhecimento de mundo e como especulação do ser no sentido da contemplação daquela criatura que "este mundo / liga em seu âmago profundo", conforme Fausto espera (v.382-383). Esse sonho será realizado como consumir o mundo. Mefisto a Fausto: "Digo-te, um tipo que especula, / é como besta, em campo árido e gasto, / que à roda um gênio man circula, / e em 
torno há verde e fértil pasto" (v.1830-1833). No entanto, Mefisto recomenda-se imediatamente ao papel de um gênio bom, que guia a mesma "besta" sobre o "verde e fértil pasto", cuja disposição natural parece ser a de ser consumido.

\section{Salto mortale em Roma, novo teor de vida no quarto gótico}

Também como um rebelde à ciência, ainda no horizonte da tradição da contemplação especulativa do mundo, Fausto aproxima-se inseguro e cauteloso à proposta do tentador - e Mefisto imediatamente o ganha: "FAUSTO. Como o faremos, pois? / MEFISTÓFELES. Vamos embora, ora essa! / Este antro de martírio acaso te interessa" (v.1834-1836). Mefisto abre a porta que leva do quarto gótico, o "antro de martírio" da consciência moderna, para a vida fulgurante. "Para a feliz jornada, apronta-te entremente!" (v.1850), exclama rapidamente Mefisto - no trecho italiano novo! - para Fausto antes que se inicie o intermezzo da entrada do estudante.

Depois da saída do estudante, Fausto retorna - nos versos que também surgiram só na Itália -: "Para onde vamos, pois?" (v.1850), pergunta inseguro a seu tentador, que, triunfante, responde: "Para onde te aprouver: / ver o pequeno mundo, e o grande, eis o mister. / Com que alegria, que proveito, / fruirás o curso e seu efeito!" (v.2051-2054).

Mefisto sintetiza a inserção do texto romano no velho manuscrito de maneira solene e felicita Fausto pelo rompimento com sua existência até o momento: "Meus parabéns e avante ao novo teor de vida!" (v.2072). O salto mortale italiano de Goethe à nova vida e à felicidade, seu renascer e seu segundo aniversário em Roma encontram portanto sua correspondência dramática e ao mesmo tempo cínico-mefistofélica na "empresa $[. .$.$] audaz" em direção ao "novo teor$ de vida" e, consequentemente, ao renascer de Fausto. Tendo em mente essa coincidência formidável da história da vida e da obra, constatar-se-á que, com a nova concepção italiana do drama fáustico, o trabalho de Sísifo vitalício realizado por Goethe começa a retratar Fausto-Mefisto como sombras de sua própria história de vida. Isso ocorre na maior parte das cenas do drama sob sinais negativos. Os erros, os apuros, as obsessões e as ilusões, as disposições à depressão e ao desespero, os quais o próprio Goethe buscou abjurar pela "conversão" - tudo isso ele transformou, similarmente à experiência italiana, na característica do seu herói dramático Fausto.

\section{Antagonistas da autolibertação: Fausto e o peregrino}

Deve ter sido sufocante para Goethe em Weimar, como para Fausto no quarto gótico. Como Fausto, Goethe irrompe do pequeno mundo, que se tornara um obstáculo à vida também para ele, e leva Fausto consigo para a fuga ao sul. Lá, porém, os caminhos de ambos os refugiados parecem se separar irreversivelmente - para, todavia, sempre permanecerem relacionados um ao outro, pois Goethe faz de Fausto o antagonista trágico de sua autolibertação. Enquanto Goethe, em Roma, frequenta a "grande escola" a fim de que a tradição europeia se torne uma palavra viva e ele se livre dos erros cardeais e geniais 
de uma existência diletante, Fausto provoca a ruptura radical com a própria ideia de Bildung. Ele protesta contra todo tipo de escola, universidade e estudo superior com um pathos titânico, rejeitado pelo viajante à Itália, e inicia a revolução, substituindo o conhecimento do mundo e a contemplação da existência por uma nova práxis e pela vontade de um novo domínio sobre o mundo. Goethe, na continuação de sua viagem à Itália, amplia a revolução espiritual fáustica contra a tradição europeia, uma revolução essencialmente direcionada ao princípio de contemplação na filosofia, até chegar a um panorama dramático da revolução política e econômica entre 1789 e 1830. O impaciente do quarto gótico se transforma cada vez mais em um típico representante da era revolucionária por meio do interminável trabalho textual de Goethe. Disso resultará um trabalho de Sísifo que encontrará sua conclusão coerente só em 1831 com o término da tragédia, que é reflexo da revolução de junho de Paris e dos versos saint-simonianos de Fausto no quarto e quinto atos.

Já em Roma, Goethe inseriu um monólogo de Mefisto no fragmento da tragédia que - agora à luz das experiências felizes de Goethe na Itália - exprime a reavaliação crítica da nova ideia fáustica romana. Sozinho no palco, Mefisto anuncia um drama tanto da aspiração infeliz e compulsiva quanto da futilidade nula. Referindo-se a Fausto: "Vai-te e despreza o gênio e a ciência, / do ser humano a máxima potência! / Deixa que em cega e feiticeira gira / te embale o demo da mentira, / E já te prendo em meu enlace. / Deu-lhe o destino um gênio ardente / que, invicto, aspira para a frente / e, em precipitação fugace, / da terra o Bom transpõe fremente" (v.1851-1859).

Comparado com a experiência eufórica do peregrino italiano de alcançar finalmente a paz no sul e poder superar aquela crise existencial sobre a qual fala em uma carta a Charlotte von Stein ("perdoe-me, luto sozinho com a morte e a vida, e nenhuma língua fala do que se passa dentro de mim"); comparado portanto com o retorno romano de Goethe à vida e seu novo teor de vida que então se inicia, será possível entender o projeto, esboçado por Mefisto, da aspiração inquieta sempre "para a frente" de Fausto como um contraconceito polêmico às experiências italianas de Goethe.

\section{Aposta}

O impulso de Fausto a um movimento aspirando sempre "para a frente" já sugere a proibição categórica do "Oh, para" como condição central do pacto, o qual Goethe acrescentaria ao texto do drama na próxima grande operação após 1797. O próprio Fausto define sua relação com Mefisto nos versos abaixo - inexplicáveis, quando se tem em mente a vivência italiana de Goethe. Fausto a Mefisto:

Se vier um dia em que ao momento

disser: Oh, para! És tão formoso!

Então algema-me a contento,

Então pereço venturoso! 
[Então] Repique o sino derradeiro,

a teu serviço ponhas fim,

pare a hora então, caia o ponteiro,

o Tempo acabe para mim! (v.1699-1706)

Se tomarmos, no entanto, a Viagem à Itália como base de comparação, escutaremos Goethe exclamar ali quase diariamente: tão formoso, incrível e inexprimivelmente formoso! Tão formosa ele encontrou a existência no sul que se demorou ali quase dois anos e várias vezes requisitou permissão para prolongar a viagem. Por sua vez, Fausto exclui da sua vida, em princípio, o momento formoso - no sentido duplo da palavra: visão formosa e momento formoso da existência. Ele pode fazer a aposta com Mefisto, como que de maneira desesperada, porque sempre soube que nunca haveria um momento formoso - por definição, jamais haveria -, pois seu Interior e o Exterior, o Eu e o Mundo, nunca poderiam se encontrar.

Entretanto, em 1790, o Mefisto do fragmento de Fausto é tão seguro de suas coisas que crê poder dispensar um pacto formal. Ele "tem" Fausto "já" "incondicionalmente", portanto sem cláusulas contratuais propriamente formuladas. Certo da vitória, Mefisto nota acerca de Fausto: "Arrasto-o, em seu afã falace, / pela vida impetuosa e nula; / lute, esperneie, se espedace, / veja sua insaciável gula / o alimento a flutuar-lhe ante a sedenta face; / debalde implore alívio refrescante, / e, se antes ao demônio já não se entregasse, / pereceria, não obstante!" (v.1860-1867).

Goethe não poderia em 1790, com as palavras de Mefisto, apresentar de maneira ainda mais destrutiva o resumo do drama que antecipa o curso da ação. "Lute, esperneie, se espedace": assim se formulam os estados mentais típicos de Fausto que foram acrescentados ao manuscrito da tragédia em Roma e que estipulam aquela vita infaustissima que desde então se relaciona polemicamente à experiência de formação [Bildung] e de felicidade de Goethe em Roma. Se isso o tivesse livrado de "ansiar, esforçar, arrastar e rastejar" em vão, poder-se-ia pensar nele "como um feliz" (Goethe, 1985, 15, p.331), como se diz ao final de junho de 1787 em Roma. Por volta da mesma época, todavia, Mefisto já podia se alegrar com os tormentos tantálicos que ainda não precisava infligir a Fausto, pois este mesmo, sempre avançando insaciavelmente "para a frente" e sempre preso ao mesmo lugar, prepará-los-á para si mesmo.

\section{Faustos na cozinha da bruxa}

Podemos observar, principalmente na cena "A cozinha da bruxa", que Goethe dá forma à caricatura ou mesmo à paródia obscena de seu próprio renascer romano nas cenas do drama escritas na Itália.

Para poder identificar algo disso, sigamos o autor do Fausto no verão de 1787 ao parque da Villa Borghese e acompanhemos as referências crípticas de Goethe à "operação cozinha da bruxa", que se inicia no velho manuscrito precisamente nessa localidade da Itália. A nova concepção do drama, que foi proje- 
tada naquele lugar clássico e, como vimos, continuou nos meses seguintes como trabalho fumegante, poderá ser lida somente como contraconceito dramático da equação eufórica entre Roma e Cupido, tendo-se em mente a felicidade italiana crescente de Goethe (até o "ponto mais extremo"), nessa mesma época, na companhia de Faustina.

$\mathrm{Na}$ "cozinha da bruxa", Goethe envia Fausto àquela esfera de pulsão onipotente da qual é excluída a reconciliação vivenciada e festejada pelo próprio Goethe em Roma entre Eros e Sexus, amor pessoal e desejo carnal, realidade e fantasia. O "fumegar" e o "esborratar" do velho texto de Fausto, sobre o qual Goethe fala cheio de mistérios, serão relacionados menos ao papel físico do manuscrito da tragédia, mas mais e antes de tudo ao seu conteúdo. Por meio dos versos inseridos em Roma, serão tisnadas também as cenas há muito tempo escritas do chamado "Urfaust". O drama de Margarida será consequentemente afetado pelo posterior esborratar do sentido do texto. "Com que alegria, que proveito, / fruirás o curso e seu efeito!" (v.2054-2054): assim Mefisto anunciou a Fausto ao deixar o quarto gótico. Esses acréscimos romanos ao texto fazem da tragédia de Margarida, já constante do velho manuscrito, o primeiro capítulo do curso frívolo de Fausto.

O renascer de Fausto ocorre em meio à confusão da essência setentrional e romântica entre bruxa, magia e névoa desprezada pelo viajante italiano. $\mathrm{O}$ observador da vida e da obra de Goethe não conseguirá encontrar muitas imagens mais paradoxais do que aquelas da "cozinha da bruxa" concebidas pelo autor italiano do Fausto e escritas justamente na Villa Borghese. Em meio ao ambiente árcade, cercado por ruínas de templos e porções de paisagem mediterrânica, Goethe esboça para a tragédia nórdica os "singulares apetrechos de feitiçaria", joga Fausto em meio a uma "mágica infernal" (v.2337), para que a "chanfana" - "um bom copo da bebida mista" (v.2519) - subtraia bons "trinta anos" da "carcaça” (v.2341-2342).

"Com esse licor na carne abstêmia", assim promete Mefisto, "verás Helena em cada fêmea" (v.2604-2605). Depois da iniciação na cozinha da bruxa, Fausto verá em cada mulher, segundo a garantia mefistofélica, o que ele deseja enxergar nelas e obter delas corporalmente; mas, de maneira alguma, enxergará o que ele próprio quer de si e para si. Por meio desse condicionamento de Fausto na "cozinha da bruxa", a operação textual amarra o drama do erudito frustrado, iniciado no quarto gótico, com a tragédia de Margarida.

\section{1: Finalização da operação fáustica}

Aqui, damos um grande salto para a fase final do trabalho no Fausto ao final da vida de Goethe.

Goethe encerra a operação no manuscrito do Fausto iniciada na Itália com as cenas da tragédia escritas no início e no verão de 1831 . O papel de adversário à sua felicidade italiana, o qual ele atribuiu a Fausto com a nova concepção romana do drama, é alcançado mais de quarenta anos depois diante do pano de 
fundo da época de revoluções que povoam esse período, chegando à sua expressão mais drástica.

Nas cenas da segunda parte do drama que surgiram a partir de 1830 , Goethe retrata Fausto aspirando aos mais importantes estágios da revolução permanente das circunstâncias de vida, revolução essa iniciada no século XIX. Começando no primeiro ato com a inflação do papel moeda que arruína o feudalismo, a tragédia assume de maneira transitória o caráter de uma passagem em revista das ideias e empreendimentos revolucionários da nova época. No segundo ato, observamos o laboratório do doutor Wagner, o aluno de Fausto, onde um homem é "fabricado" em uma retorta. Esse fabricar de pessoas de maneira técnico-industrial é como que o alvo do projeto prometeico moderno que, a partir da natureza, nega o que existe e o substitui pela segunda criação, que deve ser um produto do processo de produção moderno.

\section{O plano de Fausto: "dominar, eu, o glorioso oceano"}

Nas últimas cenas que Goethe redigiu para o drama, Fausto participa de maneira vertiginosa dessa inversão de todas as relações naturais em relações de produção. Em seu caso, o projeto de uma segunda criação assume a forma de um processo colonizador que abrange todas as condições de vida, na amplitude apresentada por Alfredo Bosi na grandiosa análise, sistemática e histórica, do processo colonizador que se desdobra no primeiro capítulo de seu livro Dialética da colonização. ${ }^{3}$ Vemos Fausto, no quarto ato (o último a ser escrito), primeiramente à beira-mar, onde é tomado pela ideia de lutar contra as ondas. $\mathrm{O}$ futuro colonizador Fausto, observando o movimento das ondas e as marés, diz:

Julguei-o acaso, e firmei bem o olhar;

A onda estacou, para depois recuar;

Após vencê-la, a vaga ignora a meta;

Chega a hora, a brincadeira reenceta.

MEFISTÓFELES ad spectatores. Que grande novidade aí se dá!

Sei disso há mais de cem mil anos já.

FAUSTO (continua apaixonadamente) Vem [a onda], sorrateira, todo canto invade,

E espalha, estéril, a esterilidade.

Cresce, incha, rola, se desfaz, e alaga

A árida vastidão da inútil plaga.

Impera onda após onda, agigantada!

Para trás volta e não realizou nada.

E me aborrece aquilo! é-me um tormento

O poder vão do indômito elemento!

Ousou transpor meu gênio a própria esfera:

Lutar quisera aí [o movimento das ondas], vencer quisera! (v.10206-10221) 


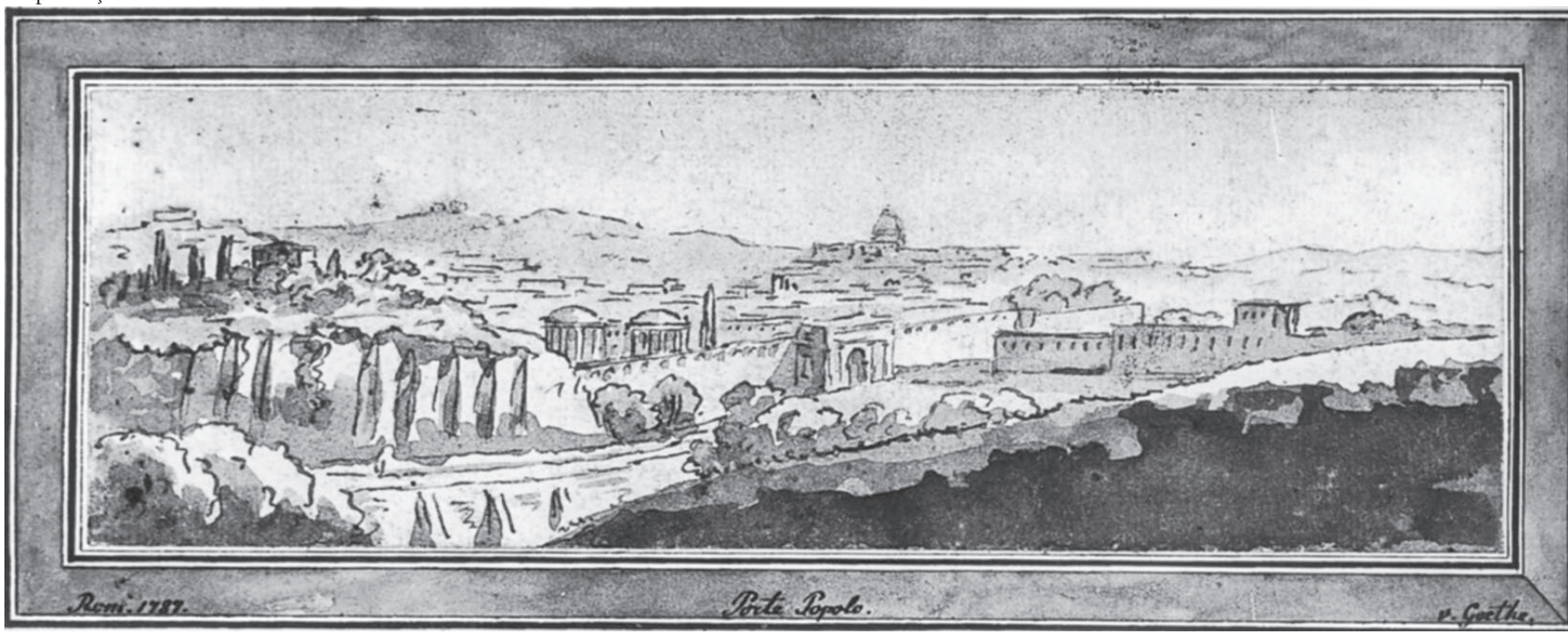

Panorama de Roma, desenho de Goethe.

No momento seguinte, Fausto determina seu grande plano de construir um dique no mar, plano que agora deverá ser apoiado justamente por Mefisto. Fausto a Mefisto:

Criei plano após plano então na mente

por conquistar o gozo soberano

de dominar, eu, o orgulhoso oceano,

de ao lençol áqueo impor nova barreira,

E ao longe, em si, repelir-lhe a fronteira.

Consegui passo a passo elaborá-lo.

Eis meu desejo, [e voltado a Mefisto] ousa tu apoiá-lo! (v.10227-10233)

\section{A entrada em cena do peregrino}

De maneira lógica, o quinto ato da tragédia nos desloca para um grande canteiro de obras, característico da época da revolução industrial, na qual as máquinas a vapor já estão em uso e canais enormes foram escavados e diques se amontoam. A transformação do mundo, que aqui é posta em movimento, está em flagrante contradição com o domínio visível das circunstâncias de vida tradicionais, aludindo-se, assim, em inúmeros motivos, à lenda da transformação de Filemon e Baucis narrada no oitavo livro das Metamorfoses de Ovídio.

Nesse enclave do clássico latino surge de repente um peregrino que se lembra do resgate do naufrágio de sua existência ao olhar para a cabana, o jardim, a capela e o bosque de Filemon e Baucis. Pode-se falar também de seu renascer.

Encalhado naquela costa onde a cabana de Filemon e Baucis já estava antes, ele agora sente necessidade de retornar ao local de seu resgate. Com o território de Filemon e Baucis diante dos olhos, o peregrino entoa os versos: 
São as velhas tílias, sim, no esplendor da anciã ramagem.

Torno a achá-las, pois, no fim, de anos de peregrinagem!

Sim, é a casa, é este o lugar;

abrigou-me ali a fortuna, quando o tempestuoso mar me lançou naquela duna.

O bom par que, com desvelo, me acolhera, eu ver quisera [segnen, abençoar, n. do. T.] (v.11043-11052)

“Torno a achá-las”, dizem as palavras de alerta específicas de Goethe nos versos do peregrino. Retornando ao velho "lugar", o peregrino lembra-se do ponto de viragem que funda a identidade de sua biografia. Ali, Filemon e Baucis cuidaram dele quando foi lançado à costa "meio morto". Agradecendo ao par prestativo, o peregrino outra vez traz à memória a cena de seu naufrágio. A seguir, voltando-se a Baucis:

Se és, mãezinha, a que percebo,

com o esposo te bendigo

pela vida do mancebo,

por vós salvo, em dia antigo.

Baucis és, que a inanimado

lábio a vida restaurou?

E, depois disso, falando a Filemon:

Filemon, tu, que, arrojado, meu tesouro à onda arrancou?

Vosso fogo, o eco argentino

da sineta na negrura, transformaram o destino

da terrífica aventura. (v.11063-11074)

O resgate da vivência do naufrágio conferiu à existência peregrina uma mudança com vistas à confiança na própria existência e à felicidade de vida, pois, ao encontro com aqueles que salvaram sua existência de maneira acolhedora, o resgate levou à experiência eufórica da humanidade. Justamente a civilização filantrópica que possibilita tal vivência encontrou uma expressão clássica na imagem de felicidade lendária dos antigos que ecoa nos nomes de Filemon e Baucis. As chamas do fogão de Filemon e Baucis e os sinos de sua capela, "o eco argentino da sineta", como se fosse o símbolo da civilização prevalente nesse idílio arquetípico, ligam-se, na perspectiva do peregrino, ao motivo de um farol, cuja luz e cujo som trouxeram orientação e sentido à aventura de sua vida em perigo.

Por ocasião do reencontro com aquele lugar no qual foi resgatado de sua crise existencial, o peregrino deseja dar uma forma espiritual à memória gratificante desse acontecimento e entoa os seguintes versos: 
Mas, deixai que eu vá mirar

do mar vasto o arco indistinto;

quero prosternar-me, orar,

tão opresso o peito sinto. (v.11075-11078)

\section{A nostalgia do peregrino}

A imagem do peregrino que observa a natureza, cuja contemplação deve provocar tranquilidade no peito oprimido, pode ser vista como um leitmotiv da obra completa de Goethe. Sua forma mais eminentemente lírica se configurou em dois poemas, a "Canção noturna do viajante" e "Uma outra [canção])". "Doce paz, / Venha, ah!, venha para meu peito!" (Goethe, 1998, 1, p.142): assim um peregrino fatigado exclama na primeira canção noturna. E a segunda canção, a "outra", o poema mais famoso de Goethe, mostra-nos como a tranquilidade da consciência se realiza na contemplação da natureza. Nessa contemplação da natureza, que durante o crepúsculo vai se aquietando cada vez mais, numa visão que dos cumes das montanhas e das frondes das árvores, passando por plantas e animais, chega ao próprio ser humano, a consciência contemplativa ganha o mesmo silêncio. "Logo / descansarás também", dizem os versos finais da meditação lírica.

Essa experiência-chave da contemplação goethiana da natureza, que subjaz à canção noturna do viajante, foi somente um prelúdio meditativo para a tranquilidade existencial da consciência que o peregrino procurou e encontrou no sul - onde ele, como está dito na Viagem à Itália, se tornou "feliz no mais alto grau em meio ao silêncio" e "se acalmou por toda a vida". Se pensarmos nos testemunhos epistolares, em que o "refugiado do norte" admitiu que lutara "com a vida e com a morte" e que "nenhuma língua" poderia enunciar a miséria da alma da qual ele foi liberto somente pelo reencontro com a própria identidade em Roma, então notaremos que os versos do peregrino no início do quinto ato do Fausto refletem mais uma vez a solução daquela "terrífica aventura" em imagens clássicas, sendo que tal solução está no centro da própria vida de Goethe: a inflexão romana, vivenciada como um "renascer", em direção à felicidade de sua existência antes "semi-inanimada".

\section{O espanto do peregrino, o emudecer do peregrino}

Já conhecemos a visão resignada de Goethe com o drama fáustico em 1831 , visão segundo a qual os tempos para exercícios contemplativos, como o edifício Fausto, evidentemente terminaram. Filemon anuncia a desordem fundamental da meditação do peregrino, a inversão da tranquilidade de consciência em espanto. Filemon menciona a Baucis, observando o peregrino andando pelas dunas: "Deixa-o ir, silenciar de espanto, / o que avista, o olhar lhe assombra" (v.11081-11082). Há poucas cenas na obra de Goethe que contêm um potencial de inquietação parecido com a entrada em cena do eufórico peregrino, que reencontra seus salvadores e, todavia, quando pretende observar o mar, é tomado de horror, corre para onde antes estava a praia, e, em consequência disso, emudece 
de espanto. A seus olhos arregalados não aparecem o mar, a areia, a natureza, nem qualquer velho "lugar". Ele contempla o projeto moderno de Fausto de uma segunda criação, desenvolvida de maneira industrial, no lugar onde o mar foi transformado em terra por meio de colossais intervenções na natureza.

No momento seguinte, depois da visão inacreditável a partir das dunas da praia, vemos "os três à mesa, no jardinzinho", ou seja, Filemon, Baucis e o peregrino. Baucis nota que o peregrino perdeu a fala e pergunta: "Mudo estás, e do alimento / nada tens na boca posto?" (v.11107-11108). O peregrino permanecerá calado até o momento catastrófico em que seu rastro se perde no inferno do território de Filemon e Baucis. Tendo em vista o que Baucis informa sobre os acontecimentos no grande canteiro de obras do dique e do canal, a transformação do mundo feita por Fausto transparece completa e terrivelmente:

[...] em noite fria,

mil luzinhas enxameavam, [chamas das máquinas a vapor,

chamadas na época de "máquinas de fogo",

que ininterruptamente trabalhavam, até mesmo de noite]

diques vias no outro dia.

Carne humana ao luar sangrava, de ais ecoava a dor mortal, fluía ao mar um mar de lava, de manhã era um canal. (v.11124-11130)

\section{A fuga de Fausto}

Se o peregrino pretendia observar o "mar vasto" para alcançar paz de consciência, Fausto cobiçava, como vimos, ao "lençol" desse mesmo mar "impor nova barreira, / e ao longe, em si, repelir-lhe a fronteira [a primitiva e interminável amplidão do mar]" (v.10229-10230).

Não bastasse isso, Goethe concebe o olhar de Fausto sobre os campos de Filemon e Baucis em exata contradição ao olhar do peregrino. Lá, soa um sino.

FAUSTO (num sobressalto)

De novo! esse tilim maldito!

Qual tiro pérfido ressoa;

meu reino à vista é infinito, por detrás, só desgosto ecoa;

maldoso, fere e me espezinha:

meu alto império é uma ilusão;

a arca das tílias, a igrejinha [a capela],

o colmo pardo [a cabana de Filemon e Baucis], meus não são.

E se eu quisesse lá folgar, traz sombra alheia tédio em si, aflige a mente, aflige o olhar; oh! visse-me eu longe daqui! (v.11151-11162) 
Se por meio do tilintar do sino no território de Filemon e Baucis o peregrino se lembra do momento de seu resgate porque quer "abençoar" ambos os velhos e o mundo deles, Fausto se desespera com esse mesmo cenário, já que ele deseja fugir. A fuga de Fausto é a resposta à bênção do peregrino. O reencontrar, rever, reouvir e renascer, e, portanto, a felicidade do peregrino que torna o velho "lugar" possível, transformam-se sob os olhos de Fausto em um local assombrado. Assim, os dobres do sino, as tílias, os jardins e a cabana se desfiguram em uma ameaça desnaturante ao "alto império". Precisamente ali onde a alma ferida do peregrino foi curada, Fausto se sente ferido de maneira ameaçadora. Consequentemente, sua fuga começa:

Esse aqui maldito! [o aqui de Filemon e Baucis]

É o que me deixa irado e aflito.

Contigo [com Mefisto], esperto e apto, é que falo;

ofende e fere-me em excesso;

não me é possível aturá-lo,

e envergonhado é que o confesso:

das tílias quero a possessão,

ceda o par velho [Filemon e Baucis em sua duna] o privilégio!

Os poucos pés que meus não são

estragam-me o domínio régio.

Lá quero armar, de braço em braço,

andaimes sobre o vasto espaço,

a fim de contemplar, ao largo,

tudo o que aqui fiz, sem embargo [...] (v.11233-11246)

A ênfase desses versos decisivos está no "eu"! Fausto quer enxergar a si mesmo nos produtos de seu trabalho precisamente ao contemplar a enorme amplidão. O mundo inteiro deve se tornar "eu", segundo a reivindicação de propriedade e domínio de Fausto, a qual reitera voluntariamente a reivindicação do projeto prometeico na variante moderna da revolução industrial. Agora, o mundo inteiro deve ser transformado em um produto, em algo inventado, fabricado.

\section{Colonização: o fim da metamorfose}

O projeto colonizador de Fausto é a resposta ao protesto contra o mundo não produzido por ele mesmo, ou seja, o ultrajante mundo que já existe. Mefisto fornece a palavra-chave: "Que cerimônia, ora! e até quando? / Pois não estás colonizando?" (v.11272-11273). É sem cerimônia que ocorre a colonização da cabana, da capela e do bosque de Filemon e Baucis. Mefisto o relata, e em suas palavras o autor do Fausto leva ao extremo o processo de citação da lenda de Filemon e Baucis, invertendo o significado das Metamorfoses de Ovídio. Mefisto a Fausto:

Mais cerimônia, então, não fiz, deles [de Filemon e Baucis] livramos-te num triz. 
Não sofreu muito o par vetusto, caiu sem vida, já, com o susto.

Um forasteiro [o peregrino], lá pousado, e que lutar quis, foi prostrado.

Na curta ação da luta brava, carvão, que à roda se espalhava, palha incendiou. Ardendo vês, lá, a fogueira desses três. (v.11360-11369)

A fogueira feita por Mefisto é o fim da metamorfose. Nesse inferno ardente, todo o Ser se decompõe no Nada, e a lei natural-filosófica da transformação evapora em meio às chamas. Nas palavras de Pitágoras, citadas por Ovídio: "Tudo se transforma, nada morre" (omnia mutantur, nibil interit). A filosofia de transformação da metamorfose de Ovídio não deixa nada se perder, nada morrer. Goethe a traduz em seu poema-legado nos versos: "Nenhuma criatura pode se decompor em Nada! / O Eterno agita-se em tudo, / Conserva-te no Ser, feliz! / O Ser é eterno; pois leis / protegem o tesouro vivo / com o qual o Todo se embeleza".

Revela-se então a dendrofobia aparentemente paranoica de Fausto, sua raiva da "arca das tílias", dos "poucos pés" que vergonhosamente lhe "estragam" o "domínio régio", sobre os quais ele deseja armar "de braço em braço, / andaimes". Goethe faz Fausto, em conluio com Mefisto, enfurecer-se contra seu [de Goethe] legado, contra o reconhecimento aplacador da metamorfose que encontrou seu símbolo poético nas tílias, nas quais Filemon e Baucis se transformam na obra de Ovídio.

\section{"Rubro ardor raízes rói"}

Precisamente nesse sentido tomaremos conhecimento do similar inferno de Linceu, o Vigia - mais uma vez, uma forma arquetipicamente antiga que lembra o eudemonismo clássico: "Felizes meus olhos, / o que heis percebido, / lá seja o que for, / tão belo tem sido!" (v.11300-11303). Enquanto isso, sabemos o que "tão belo [formoso]!" significa em Fausto. De fato, a negação da percepção enunciada nas palavras "Oh, para! és tão formoso!" está no centro do pacto que Fausto faz com Mefisto. Assim, no momento seguinte, observamos Linceu no "ardente inferno", no qual o formoso mundo de Filemon e Baucis - o lugar de felicidade do peregrino - queima nas fogueiras de Mefisto. Linceu fecha a descrição da catástrofe com os seguintes versos:

Serpenteiam chamas finas

Pelo cume da ramada.

Nos pés ocos [as tílias de Filemon e Baucis] corre a lava,

Rubro ardor raízes rói. - (longa pausa, canto)

$\mathrm{O}$ que a vista deliciava

com os séculos se foi. (v.11334-11337) 
O bosque sagrado de Ovídio arde nas chamas do drama fáustico, e nenhuma Fênix poderá mais ressurgir das cinzas desses séculos de tradição europeia. Não há em Goethe uma superação [Aufhebung] no sentido duplo da palavra, do pensamento histórico hegeliano e, depois, moderno. O processo de negação de Mefisto não deixa para o futuro algo que possa ser superado nas mudanças dialéticas do movimento histórico.

Completamente sem propósito é, portanto, o acontecimento infernal da "Noite profunda" no Fausto. "Mas nada é derramado mais sem propósito do que sangue", assim reza - nas palavras de Friedrich Dürrenmatt - o princípio fundamental do teatro do absurdo, que se recusa de modo consequente à filosofia da história na modernidade. E esse teatro do absurdo, precisamente devido a tal recusa, deve ser entendido como expressão autêntica dessa mesma modernidade, porém agora numa outra perspectiva, uma perspectiva decididamente autocrítica. Nesse sentido, a fogueira na qual Filemon, Baucis e o peregrino são incinerados já é teatro do absurdo e, como tal, teatro moderno.

\section{Notas}

1 A recém-publicada edição histórico-crítica completa do Fausto dá, especialmente em sua versão digital, uma impressão fascinante da gênese da tragédia, repleta de interrupções, errática e fragmentária; essa edição traz as diferentes partes manuscritas, cópias e impressões parciais, os acréscimos, rasuras, sobrescritos e as várias revisões feitas por Goethe: Disponível em: <http://www.faustedition.net/>. Assim nos é oferecido um bom panorama, verso a verso, da intrincadíssima gênese do Faust, seguindo o exemplo da louvável edição em paralelo dos textos do drama feita por Werner Keller (Johann Wolfgang Goethe: Urfaust-Faust. Ein Fragment-Faust. Eine Tragödie. Paralleldruck der drei Fassungen. Org. Werner Keller. 2v. Frankfurt, 1985).

2 Os versos do Fausto serão citados segundo a tradução de Jenny Klabin Segall, na edição bilíngue e ilustrada (Eugène Delacroix e Max Beckmann) com apresentação e notas de M. V. Mazzari: Primeira Parte (Editora 34, 2016, 6.ed, revista e ampliada); Segunda Parte (Editora 34, 2017, 5.ed., revista e ampliada). Sempre, porém, que exigido pela argumentação crítica do autor Michael Jaeger proceder-se-á a pequenas alterações na tradução.

3 Alfredo Bosi distingue três dimensões idealmente típicas da colonização, as quais ele faz retroceder aos significados ou formas participiais do verbo latino "colere". Em três níveis, de acordo com a fecunda hipótese de Bosi, ocorre o processo colonizador: como amanho do solo e também como apropriação política e exploração econômica do solo e como conquista da terra e submissão de seus habitantes (colo); como reivindicação de domínio no nível da consciência, da memória (coletiva) e de seus símbolos, isto é, no campo da religião e da tradição em sentido lato (cultus); e, finalmente, como projeto intelectual e técnico de construir uma identidade moderna (cultura) e projetar o futuro de maneira autônoma (Bosi, 2009, ver o $1^{\circ}$ capítulo "Colônia, culto e cultura"). Como ilustração arquetípica do processo colonizador em suas três dimensões características, pode-se conferir a sequência dramática que alude à história da vinha de Naboth $\left(1^{o}\right.$ Livro dos Reis, 21) e também as cenas em torno de Filemon e Baucis na tragédia Fausto, especialmente em suas relações com o texto-fonte latino, portanto, as Metamorfoses de 
Ovídio. Aqui, o narrador do oitavo livro resume a lenda de Filemon e Baucis com as palavras "qui coluere [i.e., coluerunt], colantur" ("quem cultuou, que seja cultuado", Ovídio VIII, v. 724). Essas palavras se tornam significativas para os acontecimentos da tragédia especialmente no horizonte da colonização aberto por Alfredo Bosi. Isso porque, em todos os níveis (colo, cultus e cultura), o processo de colonização representado por Fausto e Mefisto passa por cima do enclave de Filemon e Baucis e impulsiona a transformação do mundo. Consultei a tradução inglesa desse $1^{\circ}$ capítulo (Colony, Cult and Culture) na tradução de Robert Patrick Newcomb: Brazil and the Dialectic of Colonization. University of Illinois Press, 2015.

\section{Referências}

BOSI, A. Dialética da colonização. 4.ed. São Paulo: Cia. das Letras, 2009.

GOETHE, J. W. v. Sämtliche Werke nach Epochen seines Schaffens. München: Carl Hanser Verlag, 1985. (MA) v.16 (Aus meinem Leben. Dichtung und Wahrheit)

Sämtliche Werke. Frankfurt am Main: Deutscher Klassiker Verlag, 1994. (FA) v.7/1 (Faust. Texte)

Werke. München: Deutschen Taschenbuch Verlag, 1998. (HA) v.11 (Autobiographische Schriften III)

Fausto. Uma tragédia. Primeira Parte. Trad. Jenny Klabin Segall. Apres., comentários e notas de Marcus Vinicius Mazzari. São Paulo: Editora 34, 2004. v.1.

Fausto. Uma tragédia. Segunda Parte. Trad. Jenny Klabin Segall. Apresentação, comentários e notas de Marcus Vinicius Mazzari. São Paulo: Editora 34, 2007. v.l.

Da minha vida. Poesia e verdade. Trad. Maurício Mendonça Cardozo. São Paulo: Editora Unesp, 2017.

Faust Edition. Disponível em: <http://www.faustedition.net/>. Acesso em: $1^{\circ}$ mar. 2019.

GOETHE, J. W.; KELLER, W. (Org.) Urfaust - Faust. Ein Fragment - Faust. Eine Tragödie. Paralleldruck der drei Fassungen. Frankfurt, 1985. 2v.

GOETHES WERKE. Série I. v.26. Weimar: Hermann Böhlau, 1889. (WA)

RESUMO - Goethe nos conta em Poesia e verdade que tudo o que escreveu seria "fragmentos de uma grande confissão". Partindo das novas descobertas da filologia da edição, este ensaio busca explicitar que tal autoavaliação de Goethe se aplica antes de tudo ao seu trabalho no drama Fausto, que durou sua vida inteira. Da primeira publicação do texto em 1790 até seu término em 1831, o ensaio evidencia as rupturas na biografia de Goethe e na época goethiana. Diante do pano de fundo da época de crise europeia entre 1789 e 1830, torna-se evidente a constelação inquietante e moderna na obra completa de Goethe: o conflito irreconciliável entre Fausto e o peregrino. Nessa cena carregada de significado, escrita ao final da reformulação e da retomada do trabalho no manuscrito do Fausto, processo que no todo se estendeu ao longo de mais de sessenta anos, Goethe insere na ação dramática o sorvedouro poderoso do movimento histórico moderno que se inicia na revolução industrial. A consequente catástrofe do peregrino será entendida 
como a imagem trágica com a qual Goethe confere uma expressão simbólica à visão realista sobre o próprio anacronismo.

PALAVRAS-CHAVE: Fausto de Goethe, Peregrino, Filemon e Baucis, Metamorfoses de Ovídio, "Fragmentos de uma grande confissão".

ABSTRACT - Goethe tells us in Truth and Poetry that everything he wrote would be "fragments of a great confession." Based on new discoveries in edition philology, this essay seeks to demonstrate that Goethe's self-evaluation is applicable above all to his work on the Faust drama, which took his entire life to complete. From the first publication of the text in 1790 to its conclusion in 1831, this essay highlights ruptures in Goethe's biography and in Goethe's time. Given the background of Europe's crises between 1789 and 1830, a disquieting and modern constellation is evident in Goethe's complete works, namely, the irreconcilable conflict between Faust and the Traveler. In a scene full of significance, written at the end of the reworking and rewriting of the Faust manuscript, a process that extended over sixty years, Goethe inserts into the dramatic action the powerful maelstrom of the modern historic movement that begins with the Industrial Revolution. The consequent catastrophe of the Traveler will be understood as a tragic image with which Goethe bestows a symbolic expression to the realistic vision on anachronism itself.

KErWORDs: Faust (Goethe), The traveler, Philemon and Baucis, Metamorphoses (Ovid), "Fragments of a Great Confession".

Michael Jaeger é docente na Universidade Livre de Berlim. Publicou, entre outros livros, Fausts Kolonie - Goethes kritische Phänomenologie der Moderne [A colônia de Fausto - A fenomenologia critica da modernidade empreendida por Goethe] (Würzburg, 2004); Salto Mortale. Goethes Flucht nach Italien. Ein philologischer Essay [Salto Mortale. A fuga de Goethe para a Itália. Um ensaio filológico] (Würzburg, 2018). Ministrou cursos como professor convidado na China e nos Estados Unidos. Desenvolve atualmente, como bolsista da Fundação Siemens em Munique, uma pesquisa sobre Goethe e Marx.

@ - asmljaeger@aol.com / https://orcid.org/0000-0002-6108-9307

Tradução de Rafael Rocca dos Santos. O original em alemão - "Eine Konfession in Bruchstücken: Goethe, Faust und der Wanderer" - encontra-se à disposição do leitor no IEA-USP para eventual consulta.

${ }^{\text {I } U n i v e r s i d a d e ~ L i v r e ~ d e ~ B e r l i m, ~ B e r l i m, ~ A l e m a n h a . ~}$

Recebido em 18.3.2019 e aceito em 15.5.2019. 